\title{
The Potential Scenarios of the Impacts of Climate Change on Egyptian Resources and Agricultural Plant Production
}

\author{
Mahmoud M. Fawaz ${ }^{1}$, Sarhan A. Soliman² \\ ${ }^{1}$ Agricultural Economy Department, Faculty of Agriculture, Kafr El-Sheikh University, Kafr El-Shaikh, Egypt \\ ${ }^{2}$ Agricultural Economy Research Institute, Agricultural Research Center, Giza, Egypt \\ Email:drfawaz@yahoo.com,sarhansoliman@yahoo.com
}

Received 29 March 2016; accepted 24 April 2016; published 27 April 2016

Copyright (C) 2016 by authors and Scientific Research Publishing Inc.

This work is licensed under the Creative Commons Attribution International License (CC BY). http://creativecommons.org/licenses/by/4.0/

(c) (i) Open Access

\section{Abstract}

The emissions of greenhouse gasses in Egypt are about $0.58 \%$ of the total emissions of the world in the year 2015, although Egypt is one of the countries most affected by the impacts of climate change. By assessment and analysis of the expected economic impacts of climate change by the year 2030, the Egyptian cultivated area will be reduced to about 0.949 million acres, equal to about $8.22 \%$ of the Egyptian cultivated area compared with the case of no sinking part of the Delta land, thus reducing crop area in Egypt to about 1.406 million acres, approximately to about $6.25 \%$ of crop area compared with the case of no sinking part of the Delta land, in addition to surplus in the Egyptian balance water to about 2.48 billion $\mathrm{m}^{3}$. In this case value of the Egyptian agriculture production will decrease by about 6.19 billion dollars, equal to about $6.19 \%$ compared with presumably no sinking of the Delta land. In the case of sinking $15 \%$ of Delta lands, with the change of the productivity and water consumption of most crops, the result will be a reduction in the cultivated area to about 0.94 million acres. In addition to decreasing the Egyptian crop area to about 1.39 million acres, with a deficit in the Egyptian balance water to about 4.74 billion $\mathrm{m}^{3}$ compared to the case of no sinking part of the Delta land, the cultivated area will decrease to about $8.17 \%$, and the crop area will decrease $6.18 \%$. Also, the value of the Egyptian agriculture production will decrease by about $12.51 \%$. While compared to sinking part of the Delta land to about $15 \%$ of the total Delta area without the other impacts of climate change, the cultivated area will increase by about $0.06 \%$; the crop area will increase by about $0.08 \%$; also, the value of the Egyptian agriculture production will decrease by about $5.57 \%$.

\section{Keywords}

Climate Change, Sustainable Development, Mitigating, Environment, Global Warming 


\section{Introduction}

This phenomenon of climate change has become one of the issues, which has always been at the global level, in the light of the possible consequences of serious changes that threaten the future of the land. It was pointed out by one of the studies published by the International Organization (WMO) that the average global temperatures will rise about $4^{\circ} \mathrm{C}$ by the year 2060, presumably resulting in the rapid rise to threaten the stability of the world through the disruption of supplies of food and water in many parts of the world, particular in the continent of Africa. The negotiation that took place under care of the United Nations Framework Convention on Climate Change, which was an important turning point global agreement on climate change after the year 2020, was held in Paris in December 2015 [1]. Change in the global climate resulting from human activity has already begun, and the continuation of this change and the prospects for the response of the international community will not be quick, making the climate change more serious in the future than the estimated now, with more floods, hurricanes, and strong sea level rising up to about 59 centimeters during the current century [2] [3].

Also, it is expected that about 33 cities in the world which have nearly 8 million people, will be threatened because of the rising sea level, of which 21 cities are the most vulnerable to the risk of sea-level rise, and Alexandria in Egypt is one of those cities, although Egypt has been classified as one of the five countries in the world vulnerable to the negative impacts of climate change, such as rising sea level or sinking parts of Delta, reflected in all social and economic harm. The issue of climate change was not taken seriously in Egypt [4] [5].

On the other hand, climate change is likely to involve changes in safe conditions of food and territorial integrity with increasing pressure incoming sexually transmitted diseases through incubators, and water, as well as airborne by the food itself. The implications of this significant decline in agricultural productivity, and in labor productivity, lead to the aggravation of poverty and increasing rates of mortality. Climatic changes that occur in the time are serious drought [6], which hits some areas of the world, while rainfall causes devastating floods and torrential rains in other areas. Large emissions occurred since the beginning of the industrial revolution in Europe, leading to the emergence of the phenomenon of global warming. Thus, the most features of the global climate changes are the increase in the melting of the snow in the North and South poles, increasing the water levels in the seas and oceans and involving the risk of sinking parts of the world, especially low-lying areas. Egypt is not so long ago, and such climatic changes will affect the available natural resources, especially the relative scarcity of suppliers' feature foundations, namely, land and water resource, which will lead to direct and farreaching impact on the agricultural sector and will affect those climatic changes on the food in the world, leading to the rise of world food prices and an increase in Egyptian food invoice. Thus the pressure on the Egyptian general budget increases, and Egypt is a net importer of food [7] [8].

\subsection{Research Problem}

It is expected that Egypt would be one of the most countries affected by the impacts of climate change. These effects are reflected in high temperatures, changing patterns of rainfall, rising sea levels, and the increasing frequency of climate-related disaster risks to agriculture agricultural land, water, and food security, which may cause problems and loss of Egyptian agricultural national economy.

General, this research tries to answer to the following questions:

1) What is the impact of climate change on cultivated and crop area, productivity and consumption of water of the Egyptian major agricultural crops? And what is the impact of climate change on Egyptian water balance?

2) Is there an impact of climate change on agricultural employment and productivity agricultural labor?

3) What are the expected scenarios for impacts of climate change on the Egyptian agricultural production?

4) What is the role of agriculture to overcome climate change? And what are the ways in which they can overcome or mitigate the effects of climate change on the productivity of the major crops cultivated to reduce the impacts of climate change?

5) What are the Egyptian efforts to mitigating the impacts of climate change?

\subsection{Research Objectives}

Mainly, research stands on the expected impacts of climate change on the Egyptian agricultural production, by valuation the impacts of climate change on the impact of climate change on cultivated and crop area, productivity and consumption of water of the Egyptian major agricultural crops, also the impact of climate change on Egyptian water balance, as well as targeting research access to the best scenario possible expectations of the 
impact of climate change on the cultivated and crop area in Egypt by year 2030, to know the dangers that will befall the Egyptian agriculture production, and then the means that can overcome or mitigate such effects.

To achieve the main objective of this research seeks to achieve the following sub-objectives:

1) Identify the phenomenon of climate change, and its local dimensions.

2) Stand on the impacts of climate change on the production of the most agricultural crops, and water resources in Egypt.

3) Stand on the expected scenarios to the impacts of climate changes on the cultivated and crop area in Egypt.

4) Stand on the proposed working methods to reduce or overcome the effects of climate change on some aspects of the agricultural sector such as productivity of the major agricultural crops, as well as to the role of agriculture in overcoming the phenomenon in Egypt.

5) Stand on the Egyptian efforts to mitigating the impacts of climate change.

\subsection{Research Methodology}

The research depends on a descriptive analytical method to assess the current and future situation of the impacts of climate change in Egypt. Especially its effects on agriculture production, as well as stand on some scenarios to assess the impacts of climate change on the cultivated area and productivity of the most important agricultural crops. As well as water resources in Egypt will be in the year 2030. Drawing on the various possibilities of the impact of climate change on the productivity of the most important agricultural crops, land and water resources, and other aspects of the agricultural sector in Egypt.

\subsection{Data Sources}

The research is based on data from the Ministry of Agriculture and Land Reclamation, as well as data on the future of Egyptian agricultural development strategy for the year 2030, reports issued by the Central Agency for Public Mobilization and Statistics, the Food and Agriculture Organization of the United Nations (FAO), the World Bank, and Economic Affairs of the Ministry of Agriculture, as well as some previous studies on the subject, in addition to data and statistics published by some on the international information network.

\section{Research Results and Discussion}

\subsection{Agriculture Sustainable Development}

Sustainable development can be defined as: "Sustainable development is development that meets the needs of the present without compromising the ability of future generations to meet their own needs" [9]. The ultimate goal of sustainable development is to improve the quality of life for all members of a community and, indeed, for all citizens of a nation and the world, while ensuring the integrity of the life support systems upon which all life, human and non-human. Sustainability is the goal of sustainable development-an unending quest to improve the quality of peoples' lives and surroundings, to prosper without destroying the life-supporting systems on which current and future generations which depend on humans on. Like other important concepts, such as equity and justice, sustainability can be thought of as both a destination and a journey [10].

\subsection{Quantification of the Greenhouse Gasses in Egypt}

The quantitative estimates of Greenhouse in Egypt, as in Figure 1, that it amounted to about 197 million tons of carbon dioxide equivalent in year 2014, according to data from the Egyptian Central Agency for Public Mobilization and Statistics about the amount of emissions of carbon dioxide resulting from the consumption of oil products and gas, where it rose by about $0.1 \%$ to reach about 197.1 million tons in the year 2014 compared with about 197.0 million tons in the year 2013. While reached to about 299 million tons in the year 2015, equal about $0.58 \%$ of quantity emissions in the World, as in Figure 2.

The consumption of oil products is the main source of emissions of carbon dioxide in Egypt in the year 2014, where amounted its contribution of emissions of carbon dioxide about $40.8 \%$ of the total emissions, followed the transportation sector by about $17.6 \%$, and then the industry grew by about $16.7 \%$, while contributed to the bandits and contracting for at least amounting to about $2.3 \%$ of the total emissions, the average contribution of agriculture in the amount of emissions of carbon dioxide gas during the period (2012-2014) amounted to 15\%, 


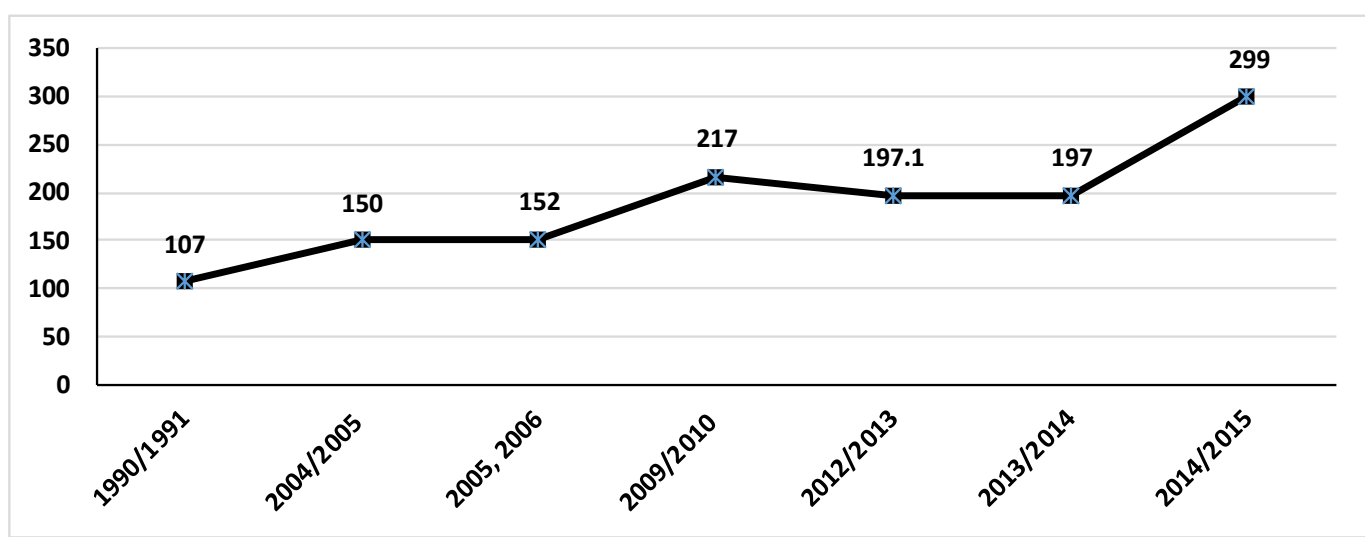

Source: Compiled and calculated from:

(1) In accordance with the inventory of greenhouse gasses, which ended in Egypt of its implementation in 1999,

(2) which was adopted on the data available for the year 1990/1991.

(2) According to the estimates International Database (World Resources Institute Washington), United States, 2006.

(3) Estimates of the Central Agency for Public Mobilization and Statistics, 2015.

\section{Figure 1. The amount of emissions in Egypt (million tons of carbon dioxide equivalent).}

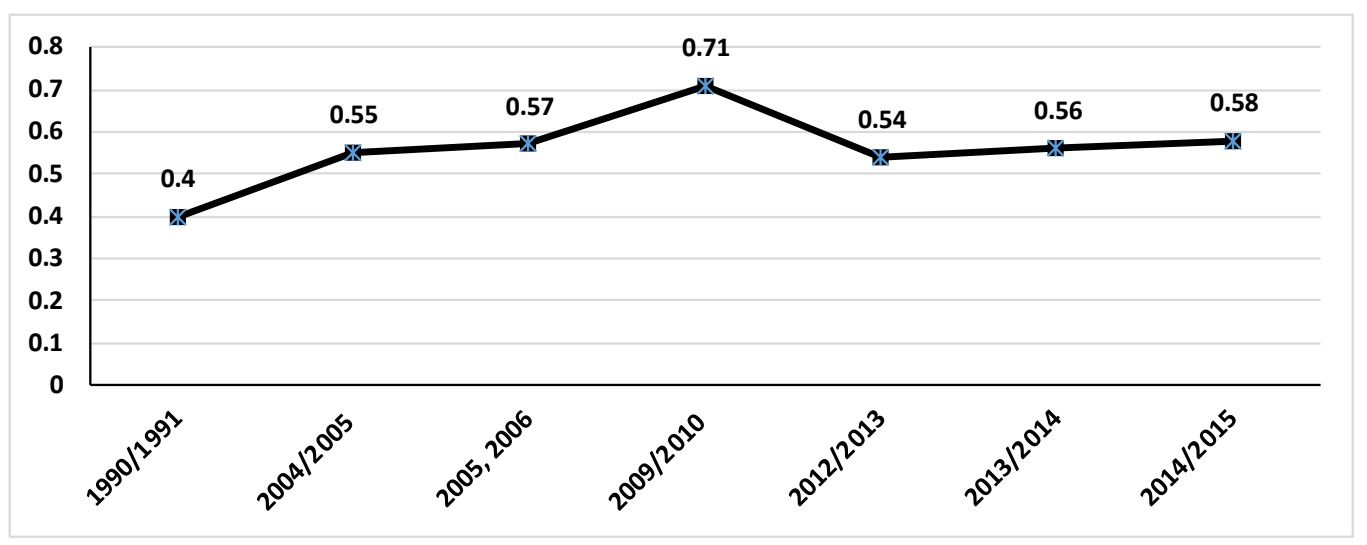

Source: Compiled and calculated from:

(1) In accordance with the inventory of greenhouse gasses, which ended in Egypt of its implementation in 1999,

(2) which was adopted on the data available for the year 1990/1991.

(2) According to the estimates International Database (World Resources Institute Washington), United States, 2006.

(3) Estimates of the Central Agency for Public Mobilization and Statistics, 2015.

\section{Figure 2. The amount of emissions in Egypt (million tons of carbon dioxide equivalent).}

and the activities for agricultural expansion caused crease in the carbon dioxide gas. Also, more than $40 \%$ of the methane gas is generated by the dissolution of organic materials in rice fields flooded, and that agriculture is responsible for about $80 \%$ of emissions of nitro oxide through analyzing the fertilizers.

Although the emissions of greenhouse gasses in Egypt not only about $0.58 \%$ of the total emissions of the world in the year 2015 but that Egypt is one of the most countries which affected by the impacts of climate change.

Agriculture is highly exposed to climate change, as farming activities directly depend on climatic conditions. Agriculture also contributes to climate change through the release of greenhouse gasses into the atmosphere. However, agriculture can also contribute to climate change mitigation by reducing greenhouse gas emissions and by sequestering carbon while maintaining food production. Mainly by producing two powerful greenhouse gasses: Methane $\left(\mathrm{CH}_{4}\right)$ from livestock digestion processes and stored animal manure; Nitrous Oxide $\left(\mathrm{N}_{2} \mathrm{O}\right)$ from organic and mineral nitrogen fertilizers. 


\subsection{Impacts of Climate Change on the Agricultural Production in Egypt}

\subsubsection{Impact of Climate Change on Agricultural Land}

The studies at the University of Alexandria estimated that between (12\% to $15 \%)$ of the area of high-quality agricultural land in production in the delta region will lose as a result of sinking or salinity with sea level rise by about half a meter only. If to consider the climatic effects of rising sea in Egypt, will consider that there is an increase in sea-level rise about one meter during the current century, given that the north coast of Egypt and more areas of Egypt declined-find that the areas that must be taken into account in covering an area ranging between $(10 \%-15 \%)$ of Delta, this in addition to the vulnerability of cultivated land in these areas and adjacent to surface water level rise increased salt in water and soil.

As well as the United Nations Environment Program (UNEP) general study of the impact of sea-level rise (expected) on the Egyptian coast and identify the area's most likely danger of drowning in the case of sea-level rise by about 0.5 meter, where it was clear that half-meter rise in sea level will lead to the sinking of a large coastal land river delta the Nile if did not take precautions for protection. And the most affected areas are the governorates of Alexandria and the lake and South Al-Barolos South downloaded on the Mediterranean Sea.

It is clear from the studies topographic coastal areas on the Red Sea, the areas of a few non-agricultural land will also be affected on the Red Sea as a result of sea-level rise, especially in the Bitter Lakes region and Suez. Consequently, will cause climate change sea level rise which would result in sinking part of the fertile agricultural land in the northern Delta, and high water level ground floor so large in another part. As well as to salting third part, this will negatively effect on the total agricultural area.

The initial expectations that the number of the population in Egypt will increase at a rate of about $1.9 \%$ annually over the next two decades, to arrive in the year 2030 to about 111 million people, while agricultural land is expected to be about 11.5 million acres in Egypt by 2030. The old land area is expected to reach about 8.4 million acres. and according to the strategy of the Egyptian Ministry of Agriculture, the target of the lately reclaimed lands will reach 3.1 million acres, so the total cultivable area will reach about 11.5 million acres, and thus the average per capita from available resources cultivated agricultural land will decrease by about $3.2 \%$ in the year 2030 from that in the year 2011, as in the Table 3.

It is clear from Table 1, and Figure 3, which shows the evolution of annual change in the average per capita from cultivated land in Egypt that this average decreasing every year, and this decline is down, where decreased by $0.4 \%$ in the (2011-2012), decreasing risen in (2012-2013) which amounted to about $0.91 \%$. It is expected to decline to about $3.2 \%$ in the year 2030, compared to his counterpart in the year 2011, or about $1.92 \%$ compared to the year 2013. Due most important reasons for this to the increasing number of residents Egypt, the largest rate of increase in the cultivated area rates in the comparative periods, in addition to the impact of climate change, which affects the ability to maintain the same average per capita level of agricultural land in the year 2030, equivalent counterpart in the year 2013.

\subsubsection{Impact of Climate Change on Productivity of the Major Crops}

Experiments conducted the unity of the Agricultural Meteorology Research and the change in the Institute for

Table 1. Available cultivated land resources in old and new lands by million acres in Egypt, now and in the future by the year 2030.

\begin{tabular}{|ccccccccc}
\hline $\begin{array}{c}\text { Cultivated land } \\
\text { resources }\end{array}$ & 2011 & 2012 & $\begin{array}{c}\text { Change } \\
(2011-2012) \\
\%\end{array}$ & 2013 & $\begin{array}{c}\text { Change } \\
(2012-2013) \\
\%\end{array}$ & 2030 & $\begin{array}{c}\text { Change } \\
(2011-2030) \\
\%\end{array}$ & $\begin{array}{c}\text { Change } \\
(2013-2030) \\
\%\end{array}$ \\
\hline $\begin{array}{c}\text { Total Cultivated land } \\
\text { resources by million } \\
\text { acres }\end{array}$ & $\mathbf{8 . 6 1 9}$ & 8.8 & 2.1 & 8.94 & 1.6 & 11.5 & 33.43 & 28.64 \\
$\begin{array}{c}\text { The population } \\
\text { by million people }\end{array}$ & $\mathbf{8 0 . 5 3}$ & 82.55 & 2.51 & $\mathbf{8 4 . 6 3}$ & 2.52 & 111 & 37.84 & 31.16 \\
$\begin{array}{c}\text { Average per capita } \\
\text { from cultivated land } \\
\text { resources by acre }\end{array}$ & $\mathbf{0 . 1 0 7}$ & $\mathbf{0 . 1 0 6 6}$ & $\mathbf{( 0 . 4 )}$ & $\mathbf{0 . 1 0 5 6}$ & $\mathbf{( 0 . 9 1 )}$ & $\mathbf{0 . 1 0 3 6}$ & $\mathbf{( 3 . 2 )}$ & $\mathbf{( 1 . 9 2 )}$ \\
\hline
\end{tabular}

Volume in brackets is negative. Source: compiled and calculated: 1) The Ministry of Agriculture and Land Reclamation, Agricultural Economics Central Department bulletin, agricultural economy, 2013; 2) Sustainable Agricultural Development Strategy until 2030, Cairo, 2009; 3) World Bank, World Development Indicators, data, separate periods. 


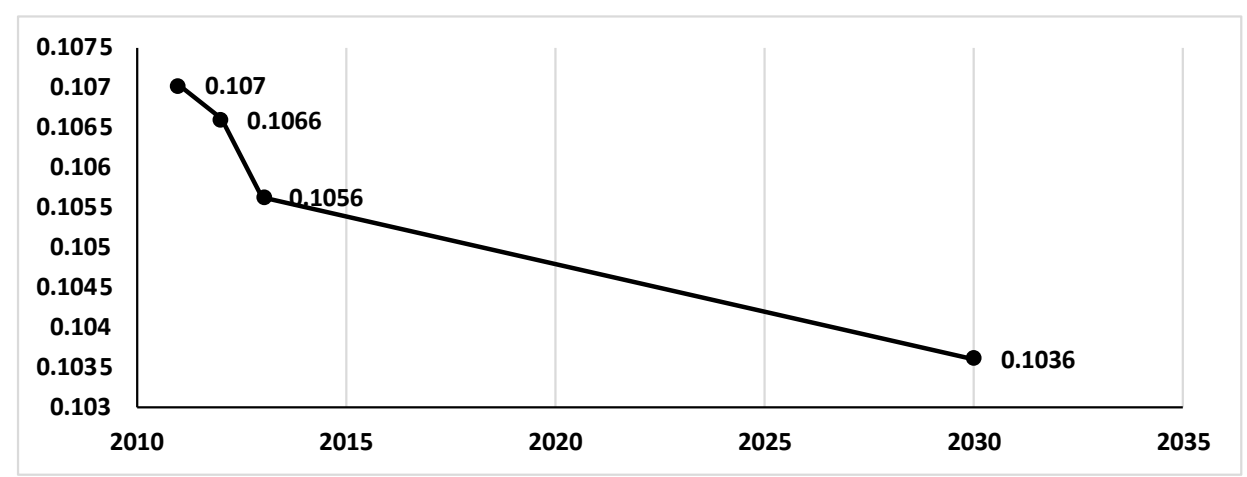

Source: Compiled and calculated from table (1).

Figure 3. Average per capita from cultivated land by acre.

land, water and Environment Research Agricultural Research Center of climate experiments, it was possible that the high degree of temperature about normal rates will affect the production of the most agricultural crops in Egypt, where he conducted experiments on the effect of high heat between $\left(1.5^{\circ} \mathrm{C}\right.$ to $\left.3.5^{\circ} \mathrm{C}\right)$ on the production per acre, where the climate change and caused by the rise in temperature of the Earth's surface will have a negative impact on the productivity of many crops in Egypt, causing severe shortages in the productivity of most major food crops in Egypt. This Experiments Included [10] of the most crops in Egypt, which each of Wheat, Barley, Corn, Sorghum, Rice, Soybeans, Sunflower, Tomatoes, Sugarcane, and Cotton, representing, a total cultivated area of these crops reached to about 8.483 million acres, representing about $54.9 \%$ of the total crop area by the year 2013 in Egypt. Refer to the impact of climate change on productivity and produce significant and influential role in plant production in Egypt and the self-sufficiency rate of these crops, also the impact of the Egyptian food balance can view the results of these Experiments for assessing the impact of climate change, and know the future scenarios, as shown in the Table 2, and the Figure 4, are as follows:

1) The productivity of wheat harvest will be less than $9 \%$ if the temperature rose by about $2^{\circ} \mathrm{C}$, and will decrease by about $18 \%$ if the temperature rose $3.5^{\circ} \mathrm{C}$.

2) Barley crop productivity will decline by about $18 \%$ (in the year 2050).

3) Corn crop productivity will be lower by about $18 \%$ in the middle of this century (when the temperature rises $3.5^{\circ} \mathrm{C}$ ), compared to productivity under current conditions.

4) Maize crop productivity high will decrease by about $19 \%$.

5) Rice crop productivity will decline by about $11 \%$.

6) Soybean crop productivity will be affected adversely under conditions of climatic changes will be the average rate of decrease in the level of the Republic in the middle of this century by about $28 \%$.

7) The sunflower productivity will decline by about $27 \%$.

8) Tomato productivity will decrease their productivity by about $14 \%$ if the temperature rose by about $1.5^{\circ} \mathrm{C}$ while this shortage will reach $50 \%$ if the temperature rose $3.5^{\circ} \mathrm{C}$.

9) Sugarcane production would fall by about $25 \%$.

10) Climate change affects a positive impact on the productivity of cotton, and would increase its productivity by about $17 \%$ at high temperature by about $2^{\circ} \mathrm{C}$, will increase the rate of increase in this crop to about $31 \%$ when the temperature rises by about $4{ }^{\circ} \mathrm{C}$.

\subsubsection{Impact of Climate Change on Water Consumption for the Major Crops}

It was possible that the high degree of temperature about normal rates will affect consumption of water for the most agricultural crops in Egypt. Experiments Included (10) of the most crops in Egypt, which each of Wheat, Barley, Corn, Sorghum, Rice, Soybeans, Sunflower, Tomatoes, Sugarcane, and Cotton, as in the Table 2, and the Figure 4, where conducted experiments on the effect of high heat between $\left(3.5^{\circ} \mathrm{C}\right)$ on consumption of water per acre, compared to water consumption under current conditions, as shown in the Table 4, and Figure 5, as follows: consumption of water of Wheat, Corn, Sorghum, Rice, Soybean, Sunflower, Tomato, Sugarcane, and Cotton crops will increase by about $2.5 \%, 8 \%, 8 \%, 16 \%, 15 \%, 8 \%, 14 \%, 2.5 \%, 10 \%$, respectively. While consumption of water of Barley crop will be reduced by about $2 \%$. 
Table 2. Impacts of climate change on productivity, consumption of water of the most important agricultural crops in Egypt by the year 2050 .

\begin{tabular}{|c|c|c|c|c|c|}
\hline \multirow{2}{*}{$\begin{array}{l}\text { Statement } \\
\text { crops }\end{array}$} & \multicolumn{3}{|c|}{$\begin{array}{c}\% \\
\text { of the productivity per acre }\end{array}$} & \multirow{2}{*}{$\begin{array}{c}\% \\
\text { of consumption of water } \\
3.5^{\circ} \mathrm{C}\end{array}$} & \multirow[t]{2}{*}{$\begin{array}{l}\text { The cultivated area } \\
\text { (thousand acres) }\end{array}$} \\
\hline & $1.5^{\circ} \mathrm{C}$ & $2^{\circ} \mathrm{C}$ & $3.5^{\circ} \mathrm{C}$ & & \\
\hline Wheat & - & (9) & (18) & 2.5 & 3378 \\
\hline Barley & - & - & (18) & (2) & 78.7 \\
\hline Corn & - & - & (18) & 8 & 2139 \\
\hline Sorghum & - & - & (19) & 8 & 335.2 \\
\hline Rice & - & - & (11) & 16 & 1419 \\
\hline Soybean & - & - & (28) & 15 & 22.4 \\
\hline Sunflower & - & - & (27) & 8 & 15.2 \\
\hline Tomatoes & (14) & - & (50) & 14 & 489 \\
\hline Sugar cane & - & - & (25) & 2.5 & 329 \\
\hline Cotton & - & 17 & 29 & 10 & 287 \\
\hline Total & - & - & - & - & 8493 \\
\hline
\end{tabular}

The volumes in brackets are negative. Source: Compiled and calculated from: the regionalization tests were conducted research unit Agricultural Meteorology climate change research institute of land, water and environment Agricultural Research Center.

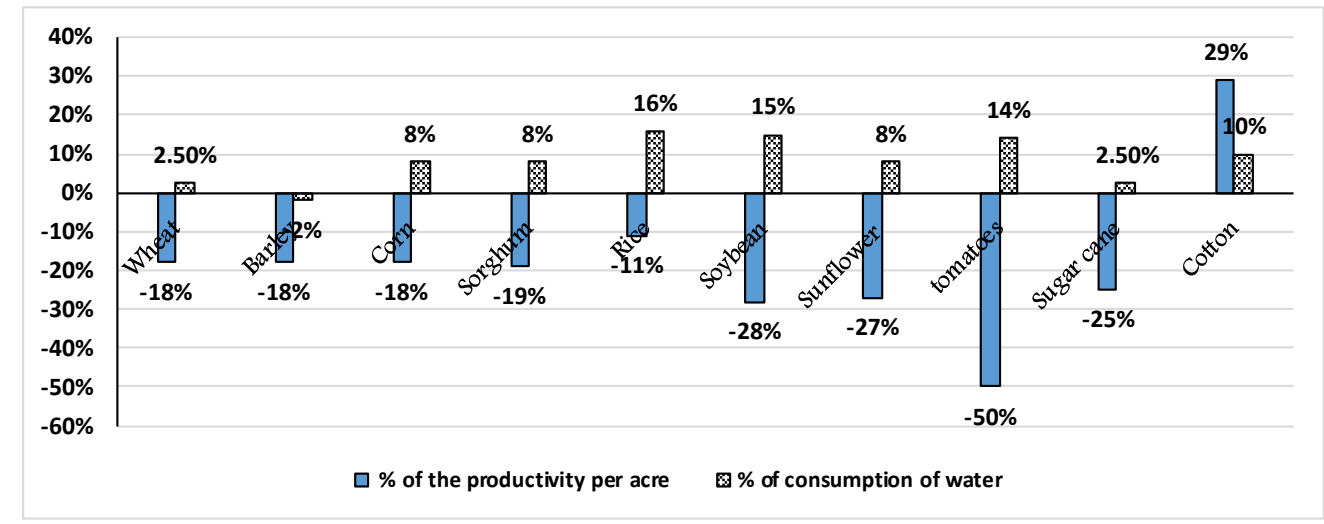

Source: from table (2).

Figure 4. Impacts of climate change on productivity, consumption of water of the most important agricultural crops in Egypt by the year 2050.

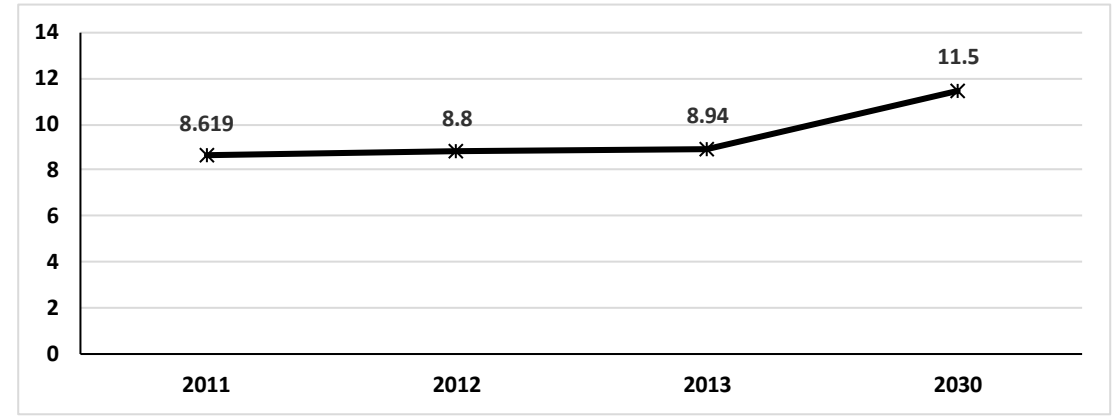

Source: Compiled and calculated from table (1).

Figure 5. Total cultivated land by million acres.

Previous results indicate refer to that the climate change will negatively affect to the productivity and consumption of water for the major crops in Egypt. 


\subsubsection{Impact of Climate Change on Desertification and Land Degradation}

Desertification is defined as: "low productive capacity of the land in the arid and semiarid land, as a result of climate change or human practices”. There is a strong and direct relationship between desertification and climate change, where the climate change lead to a desertification while increasing the desertification necessarily lead to an increase in climate change.

Egypt is one of the countries that are affected by the phenomenon of desertification as a result of all of the causes of climate change, or as a result of bad human practices, which could lead to a decline in agricultural productive capacity of the land, and there are in the current situation, referring to the direction of the quality of the land to the deterioration, the indicators of land degradation in the phenomena of increasing the land area affected salinization and high level of ground water, other phenomena of desertification, all of which lead to either exit agricultural land from the process of agricultural production finally, or to diminished productivity [11] [12].

\subsubsection{Impact of Climate Change on the Water Resources}

Egypt depends mainly on the three main sources of water: The River Nile, groundwater, and the rain, where the River Nile is the main source of water. Contributing towards by 55.5 billion $\mathrm{m}^{3}$ in the year 2013, and the average per capita of water resources in Egypt mounted by about $663 \mathrm{~m}^{3}$ in the same year, it means is under the water poverty line. It is also expected to about $582 \mathrm{~m}^{3}$ in the year 2025, uses of the available water resources raised from about 66.6 billion $\mathrm{m}^{3}$ in the year 2012 to about 74.5 billion $\mathrm{m}^{3}$ in the year 2003, by an increase mounted about $23.7 \%$. while agricultural water uses, representing to about $82.6 \%$ of the total actual uses of available water resources, which are estimated at about 74.5 billion $\mathrm{m}^{3}$ in year 2012, which is expected to be achieved toward to 78.9 billion $\mathrm{m}^{3}$ in year 2017, and an increase in the quantity of water that is recycled from about 0.9 billion $\mathrm{m}^{3}$ to 1.3 billion $\mathrm{m}^{3}$ in year 2012, with an increase of about $44.4 \%$ compared to year 2003, and is expected to reach 1.6 billion $\mathrm{m}^{3}$ in year 2017, and about 15.7 billion $\mathrm{m}^{3}$ per year, is the average unconscious irrigation networks between Aswan and fields during the period (2003-2012), lost to evaporation and leakage, which requires costly investments to reduce them, as in the Table 3.

A study of the evolution of the total available water resources in Egypt, according to data in Table 3, available water resources decreased by about $2.9 \%$ during the period (2007-2011), and expected to these resources are increased by 2030 , so arrive about 89.46 million $\mathrm{m}^{3}$, by an increase mounted by $27.33 \%$ than the total available water resources in the year 2011.

As well as, by studying of the evolution of the total water uses in Egypt, according to data in Table 4, indicating that these uses rose by about 5.15\% during the period (2007-2011), and this is expected to increase by 2030, so arrive about 98.3 million $\mathrm{m}^{3}$, by an increase of about $33.11 \%$ than the total water uses in Egypt in the year 2011.

A study of average per capita of the total available water resources and the total water uses in Egypt, as in the Table 5, and the Figure 6, Figure 7, show that the average per capita of the water resource availability in Egypt during the period (2007-2011) decreased by about $8.4 \%$, as a result low among the total available water resources in this period by about $2.9 \%$, and increasing the population by about $6.01 \%$, thus reflected a reduction of per capita of the total uses in the same period by about $0.81 \%$. Data showed in Table 5, and Figure 6, Figure 7 that the Egyptian water balance deficit amounted to about 3.59 billion $\mathrm{m}^{3}$ in the year 2011, and the deficit is expected to reach about 8.84 billion $\mathrm{m}^{3}$ in 2030 , according to previous rates on the total available water resources, the total water uses, and population growth rates.

By studying the expected effects of climate change on the Nile River water during the coming years until the year 2030, it is expected, freshwater supplies from the south to the north will be lower as a result of because of high temperatures and increased evaporation rate, which will happen in countries of the Nile sources. As well as the waters of the Mediterranean would invade northern part of the Nile Delta and is moving toward south Delta because of sea level rise. although the impact of climate change on the Nile sources is still uncertain, ranging from an increase in the quantity of rainfall accompanied by floods in Ethiopia, Sudan, and Egypt, followed by a period of drought, or a lack of rainfall with an increase in the rate of evaporation, but the likely scenario is increased rates of steaming with flat amount of rain on the sources of the Nile, which constitute $85 \%$ of the Nile water sources, and with increased evaporation rates less than Egypt's share of the Nile water. especially that 20\% of the quota to Egypt dissipates in the territory of the South of Sudan before entering the Nile in Egypt for reasons such as large subdivisions and narrow the original, with the increase in the number of the population, and therefore, increase the demand for water for agricultural, and industrial, it means a decline in the per capita share 
Table 3. Current and future available water resources in Egypt, according to the source future by the year 2030 (billion $\mathrm{m}^{3}$ ).

\begin{tabular}{|c|c|c|c|c|c|c|c|}
\hline water source & $2007 / 2008$ & $2008 / 2009$ & $2009 / 2010$ & $2010 / 2011$ & 2030 & $\begin{array}{c}\text { Change } \\
(2007-2011) \%\end{array}$ & $\begin{array}{c}\text { Change } \\
(2011-2030) \%\end{array}$ \\
\hline The Nile River & 55.5 & 55.5 & 55.5 & 55.5 & 57.5 & 0.00 & 3.60 \\
\hline Groundwater & 6.2 & 6.2 & 5.6 & 6.3 & 12.9 & 1.61 & 104.76 \\
\hline $\begin{array}{l}\text { Agricultural water } \\
\text { recycling and } \\
\text { development of } \\
\text { irrigation systems }\end{array}$ & 8 & 8 & 5.8 & 5.8 & 15.5 & (27.50) & 167.24 \\
\hline Sewage recycling & 1.3 & 1.3 & 1.3 & 1.3 & 2 & 0.00 & 53.85 \\
\hline $\begin{array}{l}\text { Rainwater and } \\
\text { Torrents }\end{array}$ & 1.3 & 1.3 & 1.3 & 1.3 & 1.5 & 0.00 & 15.38 \\
\hline Seawater desalination & 0.06 & 0.06 & 0.06 & 0.06 & 0.06 & 0.00 & $\mathbf{0 . 0 0}$ \\
\hline Total & 72.36 & 72.36 & 69.56 & 70.26 & 89.46 & (2.90) & 27.33 \\
\hline
\end{tabular}

Volumes in brackets are negative values. Source: Compiled and calculated from: 1) The Ministry of Water Resources and Irrigation, toward development strategy and management of water resources in Egypt during the period (2009-2017), august 2009. 2) In accordance with the inventory of greenhouse gasses, which ended in Egypt of its implementation in 1999, which was adopted on the data available for the year 1990-1991. 3) According to the estimates International Database (World Resources Institute Washington), United States, 2006. 4) Estimates of the Central Agency for Public Mobilization and Statistics, 2015.

Table 4. Current and future water uses in Egypt by the year 2030 (billion $\mathrm{m}^{3}$ ).

\begin{tabular}{cccccccc}
\hline Water source & $2007 / 2008$ & $2008 / 2009$ & $2009 / 2010$ & $2010 / 2011$ & 2030 & $\begin{array}{c}\text { Change } \\
(2007-2011) \%\end{array}$ & $\begin{array}{c}\text { Change } \\
(2011-2030 \%\end{array}$ \\
\hline $\begin{array}{c}\text { Agriculture } \\
\text { Losses by evaporation } \\
\text { from canals }\end{array}$ & 60 & 60 & 60 & 60.9 & 81.3 & 1.50 & 33.50 \\
$\begin{array}{c}\text { Drinking and Health } \\
\text { use }\end{array}$ & 2.1 & 2.1 & 2.1 & 2.1 & 2.1 & 0.00 & 0.00 \\
Industry & 1.33 & 1.33 & 1.35 & 1.2 & 1.3 & $(9.77)$ & 41.36 \\
Maritime & 0.2 & 0.2 & 0.1 & 0.1 & 0.1 & $(50)$ & 8.33 \\
Total & 70.23 & 70.23 & 72.05 & 73.85 & 98.3 & 5.15 & 0.00 \\
\hline
\end{tabular}

Volumes in brackets are negative values. Source: Compiled and calculated from: 1) The Ministry of Water Resources and Irrigation, toward development strategy and management of water resources in Egypt during the period (2009-2017), august 2009. 2) In accordance with the inventory of greenhouse gasses, which ended in Egypt of its implementation in 1999, which was adopted on the data available for the year 1990/1991. 3) According to the estimates International Database (World Resources Institute Washington), United States, 2006. 4) Estimates of the Central Agency for Public Mobilization and Statistics, 2015.

Table 5. Water resources and uses per capita in Egypt by the year 2030.

\begin{tabular}{|c|c|c|c|c|c|c|c|}
\hline Statement & $2007 / 2008$ & 2008/2009 & $2009 / 2010$ & $2010 / 2011$ & 2030 & $\begin{array}{c}\text { Change } \\
(2007-2011) \%\end{array}$ & $\begin{array}{c}\text { Change } \\
(2011-2030) \%\end{array}$ \\
\hline $\begin{array}{l}\text { Water resources per } \\
\text { capita by }\left(\mathrm{m}^{3}\right)\end{array}$ & 0.97 & 0.96 & 0.90 & 0.89 & 0.81 & (8.41) & $(9.74)$ \\
\hline Water uses per capita by $\left(\mathrm{m}^{3}\right)$ & 0.95 & 0.93 & 0.94 & 0.94 & 0.89 & $(0.81)$ & (5.64) \\
\hline $\begin{array}{l}\text { Surplus or deficit in water balance } \\
\text { by (billion } \mathrm{m}^{3} \text { ) }\end{array}$ & 2.13 & 2.13 & (2.49) & (3.59) & $(\mathbf{8 . 8 4})$ & - & - \\
\hline
\end{tabular}

Volumes in brackets are negative values. Source: Compiled and calculated from: 1) The Ministry of Water Resources and Irrigation, toward development strategy and management of water resources in Egypt during the period (2009-2017), august 2009. 2) In accordance with the inventory of greenhouse gasses, which ended in Egypt of its implementation in 1999, which was adopted on the data available for the year 1990/1991. 3) According to the estimates International Database (World Resources Institute Washington), United States, 2006. 4) Estimates of the Central Agency for Public Mobilization and Statistics, 2015.

of water in the year 2030.

Also of the expected impacts of climate change on water resources in Egypt that cause global warming phenomenon in Egypt in accelerating the evaporation of Nile water, and thus, reduce the freshwater resources. 


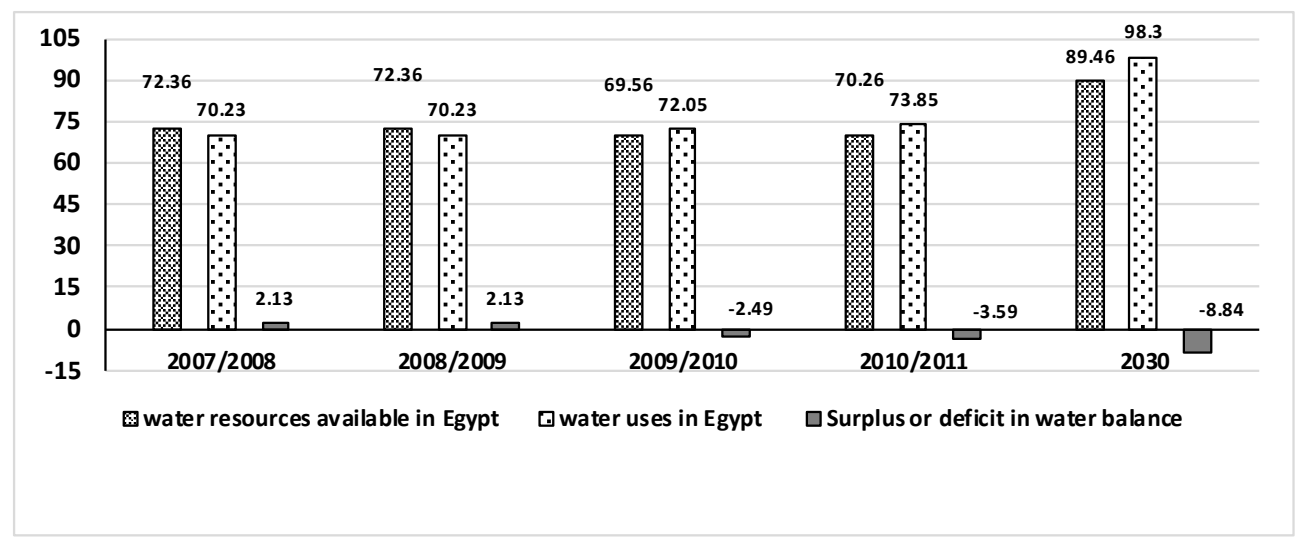

Water resources, water uses, and Surplus or deficit in water balance by billion $\mathrm{m}^{3}$ Source: from tables (4).

Figure 6. The Egyptian water balance by the year 2030.

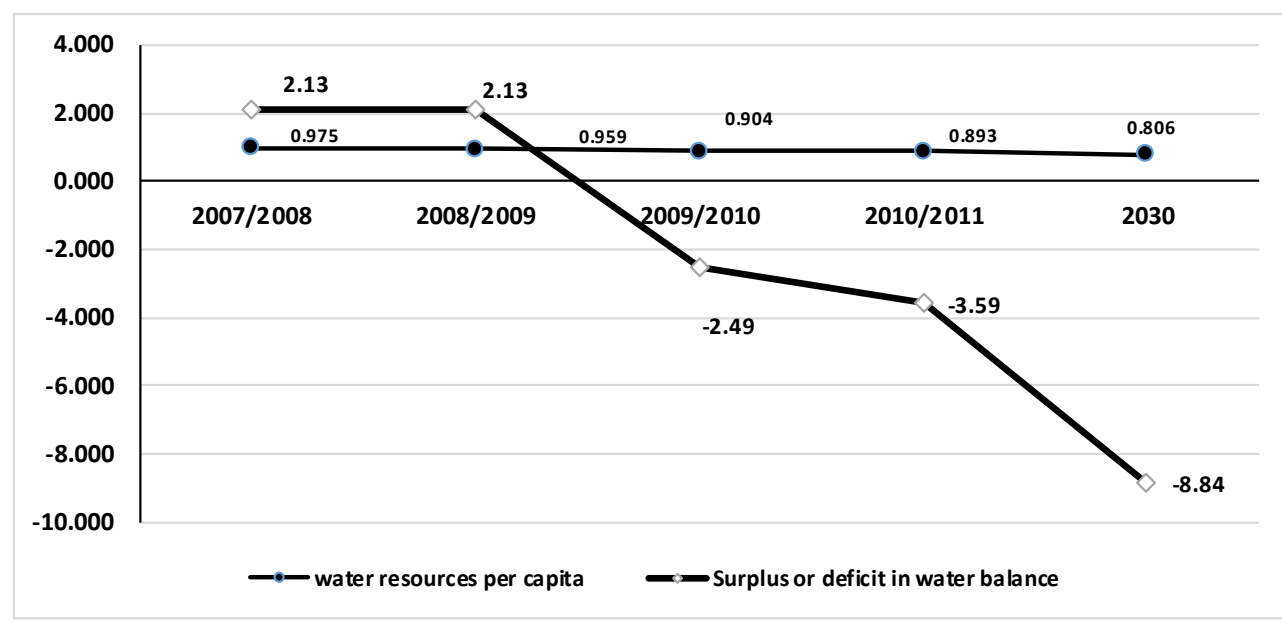

Surplus or deficit in water balances by billion $\mathrm{m}^{3}$

Water resources per capita by $\mathrm{m}^{3}$

Source: from tables (5).

Figure 7. Water uses per capita by the year 2030.

Which, in turn, will lead to the aggravation of acute shortage of Egypt in the field of drinking water, irrigation and power generation.

It is expected to be affected by each water resources and demand negatively with climate change as follows:

1) The high temperature will lead to increased evaporation, and increasing the quantities needed by consumption of agriculture and industry.

2) The change in patterns of rainfall will lead to a shortage of water in coastal areas.

3) The increase in the dust industrial pollutants and consumption human consumption also increased salinity in the soil would lead to the deterioration of water quality.

4) Sea-level rise will increase the penetration of salinity in the soil and leads to the pollution of groundwater sources in coastal areas.

5) As long as decreased resources of the river, it will withdraw this lack of underground water accumulated in the River Delta was nominated.

6) As a result of decreased the water of the river, the Desert aquifers are not expected vulnerability to climatic changes, however, in the case of reservoirs to receive feed nominated by the river.

Previous results agreed with the results of studies conducted on the subject, agreed with all of "sentini" [13], and "strzepek" [14] studies about the effects of climate change on the future of the River Nile. 


\subsubsection{Impact of Climate Changes on the Agricultural Labor}

It is expected that approximately about 6 million Egyptian citizen in the northern Delta may be subjected to displacement in the year 2030, due to the floods and high water level in the Mediterranean, where Egypt had been classified as one of the five countries in the world are the most vulnerable to the negative impacts of climate change, rising sea level or sinking parts of Delta and reflected in all of the social and economic harm, As a result, it is expected lost some of the agricultural lands, which would lead some of the millions to leave their areas and migration to new areas, it is estimated that the total number of displaced persons in the case of potential sea level rise $30 \mathrm{~cm}$ mounted by about 70.4 thousand job of the agricultural labor in the area north of Delta [15], as in the Table 6.

The high temperature is expected to adversely affect agricultural productivity, and hence affected agricultural production with the loss of a portion of agricultural land, labor shortages as a result of displacement, in addition to the declining productivity of the agricultural worker, and also decrease the productivity of most crops, negatively affects Egypt's total agricultural output and food self-sufficiency ratio as a result of the high degree of motion.

\subsection{Expected Scenarios for Impacts of Climate Change on the Agricultural Production in Egypt}

Assessment and analysis of the expected economic impacts of climate change by 2030, on the main economic variables relating to such cultivated area, crop area and productivity of major crops. Also regarding the possibility of sinking part of the Delta land to about 15\% of the total Delta area. In addition, to the expected impacts on water balance in Egypt. With the evolution of each of the variables: population and agricultural intensification, in the end, to estimate the impact of climate change on agricultural production value.

So can view the most important variables been taken into account in assessing the impact of climate change on sustainable agricultural development in Egypt as follows:

1) Cultivated area.

2) Crop area.

3) Population growth rate.

4) An amount of water used for agriculture and other uses.

5) Water quantity expected from natural sources.

Estimation of the expected impacts of climate change on the agricultural production value, as the final outcome of the anticipated changes in the variables influencing the value of this output. The assessment of expected impacts was limited to plant sector, where agricultural production includes other sectors such as fisheries and livestock, can were estimated for three scenarios:

1) Scenario no. 1-the optimistic scenario-with presumably no sinking of the Delta land, and the absence of an effects of climate change on the variables in the valuation.

2) Scenario no. 2-pessimistic scenario-where is the estimation of the expected impacts of climate change with probability sank $15 \%$ of the Delta land, assuming no changes due to climate change on other variables.

Thus the difference between scenario no. 2 and scenario no. 1, represents the impact probability of sank 15\% of the Delta land on the Egyptian agricultural production as the potential impact of climate change.

3) Scenario no. 3-the most pessimistic scenario-has been added to the potential impact of climate change on the productivity of most crops and water consumption.

So the difference between scenario no. 3 and scenario no. 2 represents the effect of the potential impact of climate change on crop productivity, and crop water consumption, in addition to sinking $15 \%$ of the Delta land.

The following is an overview of these estimates, with an assumption of a steady crop intensification at 1.99 in all scenarios, as in the Table 7, Table 8, accordingly, it is expected that:

Table 6. Estimates of losses in the agricultural labor as a result of sea-level rise in Egypt.

\begin{tabular}{ccccc}
\hline $\begin{array}{c}\text { The increase in the } \\
\text { sea-level }\end{array}$ & Year & Losses in area & \% of the total area & $\begin{array}{c}\text { The number of jobs lost } \\
\text { (thousand job) }\end{array}$ \\
\hline $18 \mathrm{~cm}$ & $\mathbf{2 0 1 0}$ & $\mathbf{1 4 4} \mathbf{k m}^{\mathbf{2}}$ & $\mathbf{0 . 0 1 4 4}$ & $\mathbf{3 2 . 5}$ \\
$30 \mathrm{~cm}$ & $\mathbf{2 0 3 0}$ & $\mathbf{1 9 0} \mathbf{k m}^{\mathbf{2}}$ & $\mathbf{0 . 0 1 9}$ & $\mathbf{7 0 . 4}$ \\
\hline
\end{tabular}

Source: Compiled and calculated from: El-raey M. (2000). (ECRP): coastal zone development and climate change drill down of climate change on Egypt. 
Table 7. Expected scenarios for cultivated and crop area with future water resources by the year 2030 in light of the sinking and without sinking 15\% of Delta lands by the year 2030 .

\begin{tabular}{|c|c|c|c|c|c|c|}
\hline \multirow[b]{2}{*}{ The statement } & \multirow[b]{2}{*}{2011} & \multicolumn{2}{|c|}{2030} & \multirow[b]{2}{*}{$\begin{array}{c}\text { Change } \\
\text { Between } \\
(1),(2)\end{array}$} & \multirow[b]{2}{*}{$\begin{array}{c}\text { Change } \\
\text { between } \\
(1),(2) \%\end{array}$} & \multirow{2}{*}{$\begin{array}{c}\text { Estimates } \\
\text { agricultural } \\
\text { development } \\
\text { strategy for the } \\
\text { year } 2030\end{array}$} \\
\hline & & $\begin{array}{c}\text { Scenario (1) } \\
\text { without sank 15\% } \\
\text { of the Delta lands }\end{array}$ & $\begin{array}{c}\text { Scenario (2) } \\
\text { with sank 15\% } \\
\text { of the Delta } \\
\text { lands }\end{array}$ & & & \\
\hline $\begin{array}{l}\text { The cultivated } \\
\text { (million acres) }\end{array}$ & 8.619 & 11.549 & 10.6 & $(0.949)$ & (8.22) & 11.549 \\
\hline Crop intensification & 1.806 & 1.99 & 1.99 & - & - & 1.99 \\
\hline $\begin{array}{c}\text { Crop area } \\
\text { (by million acres) }\end{array}$ & 15.57 & 22.5 & 21.094 & (1.406) & $(6.25)$ & 22.984 \\
\hline $\begin{array}{c}\text { Population } \\
\text { (by million person) }\end{array}$ & 78.69 & 111 & 111 & - & - & 111 \\
\hline $\begin{array}{l}\text { Water used in agriculture } \\
\quad\left(\text { by billion } \mathrm{m}^{3}\right)\end{array}$ & 60.9 & 81.3 & 74.94 & (6.36) & (7.82) & - \\
\hline $\begin{array}{l}\text { Water used in drinking and } \\
\text { health (by billion } \mathrm{m}^{3} \text { ) }\end{array}$ & 9.55 & 13.5 & 13.5 & - & - & - \\
\hline $\begin{array}{l}\text { Other used of water } \\
\quad \text { (by billion } \mathrm{m}^{3} \text { ) }\end{array}$ & 3.5 & 3.5 & 3.5 & - & - & - \\
\hline $\begin{array}{l}\text { Total used of water } \\
\quad\left(\text { by billion } \mathrm{m}^{3} \text { ) }\right.\end{array}$ & 65.72 & 98.3 & 91.94 & (6.36) & (6.47) & - \\
\hline $\begin{array}{l}\text { Water resources } \\
\text { (by billion } \mathrm{m}^{3} \text { ) }\end{array}$ & 62.13 & 89.4 & 71.52 & (17.88) & $(20.0)$ & - \\
\hline $\begin{array}{l}\text { Balance of water } \\
\text { (by billion } \mathrm{m}^{3} \text { ) }\end{array}$ & (3.59) & (8.84) & (2.48) & 6.36 & (71.95) & - \\
\hline $\begin{array}{c}\text { Value of agricultural } \\
\text { production } \\
\text { (by billion dollars) }\end{array}$ & 35.112 & 84.22 & 78.03 & (6.19) & (7.35) & - \\
\hline
\end{tabular}

Volumes in brackets are negative. Source: Compiled and calculated from: Tables 1-6.

Table 8. Expected scenarios for cultivated and crop area with future water resources by the year 2030 in light of the impacts of the climate change.

\begin{tabular}{|c|c|c|c|c|c|}
\hline \multirow{2}{*}{ The statement } & 2030 & \multirow{2}{*}{$\begin{array}{c}\text { Change } \\
\text { between (1), } \\
\text { (3) }\end{array}$} & \multirow{2}{*}{$\begin{array}{c}\text { Change } \\
\text { between } \\
(1),(3) \%\end{array}$} & \multirow{2}{*}{$\begin{array}{c}\text { Change } \\
\text { between } \\
(2),(3)\end{array}$} & \multirow{2}{*}{$\begin{array}{l}\text { Change } \\
\text { between } \\
\text { (2), (3)\% }\end{array}$} \\
\hline & $\begin{array}{c}\text { Scenario (3) } \\
\text { included change climate }\end{array}$ & & & & \\
\hline $\begin{array}{l}\text { The cultivated } \\
\text { (million acres) }\end{array}$ & 10.606 & $(0.94)$ & (8.17) & 0.006 & 0.06 \\
\hline Crop intensification & 1.99 & - & - & - & - \\
\hline $\begin{array}{c}\text { Crop Area } \\
\text { (by million acres) }\end{array}$ & 21.11 & (1.39) & (6.18) & 0.016 & 0.08 \\
\hline $\begin{array}{c}\text { Population } \\
\text { (by million person) }\end{array}$ & 111 & - & - & - & - \\
\hline $\begin{array}{l}\text { Water used in agriculture } \\
\quad\left(\text { by billion } \mathrm{m}^{3}\right)\end{array}$ & 77.19 & (4.11) & (5.06) & 2.2482 & 3.00 \\
\hline $\begin{array}{l}\text { Water used in drinking and } \\
\text { health (by billion } \mathrm{m}^{3} \text { ) }\end{array}$ & 13.5 & - & - & - & - \\
\hline $\begin{array}{l}\text { Other used of water } \\
\quad\left(\text { by billion } \mathrm{m}^{3} \text { ) }\right.\end{array}$ & 3.5 & - & - & - & - \\
\hline $\begin{array}{l}\text { Total used of water } \\
\quad{\text { (by billion } \mathrm{m}^{3} \text { ) }}^{\text {by }}\end{array}$ & 94.19 & (4.11) & (4.18) & 2.25 & 2.45 \\
\hline $\begin{array}{l}\text { Water resources } \\
\left(\text { by billion m }{ }^{3} \text { ) }\right.\end{array}$ & 89.41 & 0.01 & 0.0 & 17.89 & 25.0 \\
\hline $\begin{array}{l}\text { Balance of water } \\
\text { (by billion } \mathrm{m}^{3} \text { ) }\end{array}$ & (4.74) & 13.58 & - & $(7.22)$ & - \\
\hline $\begin{array}{c}\text { Value of Agricultural } \\
\text { production (by billion } \\
\text { dollars) }\end{array}$ & 73.68 & (10.54) & (12.51) & (4.35) & (5.57) \\
\hline
\end{tabular}

Volumes in brackets are negative. Source: Compiled and calculated from: Tables 1-6. 
In the case of potential sank $15 \%$ of Delta lands: the cultivated area will be reduced by about 0.949 million Acres, equal about $8.22 \%$ of the cultivated area compared by with the case of no sinking part of the delta land, thus reduced crop area about 1.406 million acres, approximately by $6.25 \%$ of crop area comparing in the case of no sinking part of the delta land. In addition to surplus in the Egyptian balance water by about 2.48 billion $\mathrm{m}^{3}$. In this case value of the Egyptian agriculture production will decrease by about 6.19 billion dollars, equal about 6.19\% compared by presumably no sinking of the Delta land.

In the case of sinking 15\% of Delta lands, with the change of the productivity and water consumption of most crops: the result will be a reduction in the cultivated area of about 0.94 million acres, and thus decrease the crop area by about 1.39 million acres, with deficit in the Egyptian balance water by about 4.74 billion $\mathrm{m}^{3}$. Compared this results with scenario no. 1, the cultivated area will decrease by about $8.17 \%$, and the crop area will decrease $6.18 \%$, also the value of the Egyptian agriculture production will decrease by about $12.51 \%$, while Compared this results with scenario no. 2, the cultivated area will increase by about $0.06 \%$, and the crop area will increase by about $0.08 \%$, also the value of the Egyptian agriculture production will decrease by about $5.57 \%$.

In addition, the effects of climate change on each of the most crops productivity as well as an agricultural labor productivity, the expected effects on each of the cultivated and crop area, it will be seen that agricultural production will be negatively affected by these changes, and thus, would be reflected on the adequacy of agricultural production and the ratio of self-sufficiency of different crops, thus on the national economy, generally.

Therefore, the scenarios were expected (scenario 2, 3), in the year 2030, as a result of the impact of climatic changes, completely different from the Egyptian expectations of agricultural development strategy for the year 2030, where it was did not take into account the change climate effects of expected until the year 2030, have been targeted at key strategic targets sustainable agricultural development in year 2030, it has not, however, take within these objectives the impact of projected climate change, although this aspect is extremely important, and it has a significant impact in accordance with the scenarios is expected to be no. 2, 3.

Previous results that have been evaluated, agreed with many of the studies in the same object, where the negative impacts of climate change and the increase expected population, this would lead to a decline in expected, estimated by about $12 \%$ in value agriculture agricultural production by the year 2030, also, an increase of about $16 \%$ in the value of the purchase prices loss of job opportunities, which is estimated at $2 \%$ of the total current employment, As well as the climate change will reduce the Egypt's GDP by about $10 \%$ in the year 2050 [7].

\subsection{Ways to Face of the Climate Change Phenomenon in Egypt}

This is done through the following:

1) Generally, there are some of the methods are known in the face of climate change, including: Mitigation: to reduce the greenhouse gas emissions from different sectors, through the use of clean technology, fuel substitution, the use of renewable energies such as the wind, the Sun, tubing, and vitality. Adaptation: resulting from such circumstances such as devising new strains of crops, which bear the high temperature and salinity, optimum use of water resources through the application of the policies of rations and rationalize water consumption.

2) The formulation of a policy of integrated coastal areas management and development integrated coastal zone management, taking into account the potential rise in sea level with the monitoring of the implementation of this policy continued monitoring (through remote sensing, for example), the operational ways to modify the route in the case of errors.

3) The severe shortage of available data and information on the negative effects of climate change on different sectors of development in Egypt, in particular the issue of the internal and external migration, and the establishment of a full database continually occurring, in advance of the study, the promotion of scientific research and technology in all issues related to climate change and develop specific plans and financing is clear.

4) Therefore, it is necessary to the cultivation of wheat bear the high temperatures. As well as to resist drought in time with a good distribution of items wheat to the geographical regions, and the expansion of winter crops such as lentils, beans, and other municipal, it is likely that these measures to prevent expected negative effects, or, at least, mitigate the negative effects [6].

5) The regionalization studies of the most important means to reduce the negative impact and further improve the positive impact of this phenomenon, there have been many studies of regionalization in this regard was the result of the possibility to overcome, or, at least, alleviate the shortage in crops productivity, which adversely affected by this phenomenon. 
6) There are many of the results of the studies conducted on the regionalization of crops, which has been a study sensitivity under conditions of climatic changes, which could be on the way to ease the shortage the accident, whether in crop productivity or net revenues of farm crop yield per acre or unit of water, in general, the most important results of the regionalization studies proposed the following: to develop new types of high temperature, salinity and drought and the conditions that will prevail under conditions of climate change, and to develop new types of short growth season to reduce water requirements necessary for it, as well as to change the dates for agriculture, including appropriate to weather conditions, as well as cultivation of new items in appropriate areas to the appropriate climate for increasing the yield of crop harvest water for each unit. reduce wasteful crop area in water consumption, or at least not to increase the size of (such as rice and sugarcane), and plant alternative crops are given the same purpose and water consumption season and lower growth such as the cultivation of sugar beet, instead of sugar cane (in this strategy should take into account that this crop is a major crop in Upper Egypt, in addition to the factories secondary industries and employment based on this crop).

7) Irrigation water at appropriate time's appropriate quantity in each effect in order to preserve every drop of water, which will be in need of it under conditions of climate change.

\subsection{The Role of Agriculture in Mitigating the Impacts of Climate Change in Egypt}

As regards the future of agriculture under the changing climate, a range of adjustment, measures can be undertaken relating to farming practices, for example, planting, harvesting and watering/fertilizing existing crops, using different varieties, diversifying crops, implementing management practices. Mitigation has the potential to reduce climate change impacts, and adaptation can reduce the damage of those impacts. Together, both approaches can contribute to the development of societies that are more resilient to the threat of climate change.

Can significantly reduce emissions of greenhouse gasses resulting from agriculture through many means, the most important of which are:

1) The use of coping mechanisms that resist climate change, through specific activities such as use of crops resistant to drought or salinity, and use of water resources in the most efficient manner, in addition improvement in the management of pesticides, as well as can include changes in agricultural patterns, reducing the use of fertilizers and develop the production of rice.

2) Farming can contribute to a positive in reducing emissions of carbon dioxide by absorbed, where it is estimated that the contribution of cropland in carbon sink during the twentieth and thirtieth next year ranging from 450 to about 610 million tons of carbon each year, the application of the methods of best in land management as improving fork soil water management and erosion control, conversion of cropland in the industrial countries to permanent forest or grassland or ecological systems, living biomass crops, to plow soil for maintenance, and other farming can have a major role in carbon sink compensatory mechanism on the contribution of agriculture to greenhouse gases.

3) It also could be that agriculture plays an important role in reducing the burning of fossil fuels, it is possible to replace $20 \%$ of fossil fuel consumption in the short term using biomass fuel live Such as herbs, which fast growth, oilseeds agricultural residues provide great potential as alternatives to generate energy.

\subsection{The Egyptian Efforts Exerted to Face the Effects of Climate Change}

Egypt responded with efforts to cope with the challenges of climate change and improve their conditions of life, establish the rules of sustainable development in the world, and where that Egypt is one of the countries that are expected to be affected by the impacts of climate change, especially in the sectors of agriculture, water resources, as well as drinking, and health. Therefore, has focused on the need to activate the State policies of response measures to cope with and mitigation of the consequences of climate change. Egypt made many efforts and activities to deal with the issue of climate change, including:

1) The ratification of the Convention on the United Nations Climate Change and environment law No. 4 in the year 1994, and participation in all international conferences and workshops on Climate Change, to avoid imposing any international obligations on the developing countries, including Egypt, and ratification of the Kyoto Protocol and forming a national committee for the Clean development mechanism (CDM) in the year 2005, includes the Egyptian Office and the Egyptian clean development mechanism, and the report of national reporting in the year 1999 to limit greenhouse gases and national plan of action to climate change.

2) The Ministry of Electricity and Energy work of many projects in the field of New and Renewable Sources 
of Energy (wind-solar-water-biotechnology) and encourage projects to improve energy efficiency, and the Ministry of Water Resources and Irrigation Projects to protect the beaches (the protection of the coast), as well as the establishment of competent research institutes in collaboration with development partners, and the Agricultural Research Center to conduct some research on the impact of climate change on crop production and to devise new types have the ability to take the heat, and the establishment of the Ministry of the environment work Pilot projects to encourage the private sector to invest in clean energy projects, treatment of wastes and the establishment of forest plantations, and the establishment of the Ministry of the environment is currently preparing a report national reporting II to be the basis of the updated national plan of action to climate change, and update inventories of greenhouse of various sectors.

3) The restructuring of the national climate change in the year 2007 to coordinate at the national level with regard to the topics of climate change, and the perception of policies and strategies to deal with these issues, and to propose mechanisms for implementation.

4) Maximizing Egypt's benefit from the mechanisms of the Kyoto Protocol through the implementation of the clean development mechanism projects, where guest approval on a number (36). The draft in the framework of the mechanism, including sectors of New and Renewable Sources of Energy, Industry, waste treatment, afforestation, and improve the efficiency of energy conversion of fuel, natural gas, at a total cost about 1.200 million dollar, represent these projects attractive to foreign investment, and providing new job opportunities, and to contribute to the implementation of the sustainable development plans in the State.

5) The plan targets National Climatic changes need to exchange information to reach real dimensions of the phenomenon of climate change environmental repercussions, and that one of its axes is the cooperation with the international community in maintaining the quality of the environment and reducing the causes of climate change, the plan includes the areas of raising the public awareness of the phenomenon and deal with economic dimensions, capacity-building, and international financial and technical assistance programs, as well as the transfer of technology, and to develop the necessary policies and programs to adapt to climate changes in all sectors, with the participation of non-governmental associations and organizations [15] [16].

6) The Egyptian Agricultural Policy can offer a number of instruments to find adequate to answer to the challenges of climate change, a more sustainable of Egypt agriculture. Given the pressure on natural resources, agriculture has to improve its environmental performance through more sustainable production methods. Farmers also have to adapt to challenges stemming from climate change, and have to pursue mitigation and adaptation actions, (e.g.) by developing greater resilience to disasters, such as flooding, drought, and fire.

\section{Conclusion}

Despite the fact that the phenomenon of global climate changes, and the local impacts, it is expected that Egypt would be one of the countries most affected by the effects of climate change. These effects are reflected in high temperatures, changing patterns of rainfall, rising sea levels, and the increasing frequency of climate-related disasters, which pose risks to agriculture, land agriculture, water supply, and food security. The research focuses on the phenomenon of climate change, the reasons for their occurrence, and the impact of climate change on agricultural land; productivity of the most agricultural crops, water resources, and productivity of agricultural worker; scenario's expected effect of climate changes of the area cultivated and crop area in Egypt. Therefore, research aimed to expect the impacts of climate change on the agricultural land, productivity of the most agricultural crops, and water resources, as well as access to the best scenario's possible expectations to the impact of climate change on the cultivated crop area in the year 2030. The descriptive research adopted an analytical method to find out the current situation and the future image of climate change, in addition to its effects on agriculture, as standing on scenarios to assess climate change impacts on agricultural land and productivity, and also water resources in the year 2030. The most research results are as follows: the quantity of greenhouse gases in Egypt was about 197 million tons of carbon dioxide equivalent in the 2014; there is the possibility of losing about $15 \%$ of the area of high-quality agricultural land in the Delta region as a result of sinking or salinity with sea level rise by about half a meter away; it is expected that climate change will have a negative impact on the productivity of field crops. By assessment and analysis of the expected economic impacts of climate change by the year 2030, the cultivated area will be reduced to about 0.949 million acres, equal to about $8.22 \%$ of the total cultivated areas compared with the case of no sinking part of the Delta land, and thus crop area will reduce about 1.406 million acres, equal to about 6.25\% of the total crop areas in Egypt compared with the case of no sinking part of the Delta land in addition to surplus in the Egyptian balance water by about 2.48 billion $\mathrm{m}^{3}$. In this case, 
value of the Egyptian agriculture production will decrease by about 6.19 billion dollars, equal to about $6.19 \%$ compared with presumably no sinking of the Delta land. In this case, value of the Egyptian agriculture production will decrease by about 6.19 billion dollars, equal to about 6.19\% compared with presumably no sinking of the Delta land. In the case of sinking $15 \%$ of delta lands, with the change of the productivity and water consumption of most crops, the result will be a reduction in the cultivated area of about 0.94 million acres, and thus the crop area decreases by about 1.39 million acres, with deficit in the Egyptian balance water to about 4.74 billion $\mathrm{m}^{3}$ compared to the case of no sinking part of the Delta land. The cultivated area will decrease by about 8.17\%; the crop area will decrease $6.18 \%$; also, the value of the Egyptian agriculture production will decrease by about $12.51 \%$ compared to sinking part of the Delta land to about $15 \%$ of the total delta area without the other impacts of climate change; the cultivated area will increase by about $0.06 \%$; the crop area will increase to about $0.08 \%$; also, the value of the Egyptian agriculture production will decrease by about $5.57 \%$.

\section{Recommendations}

It is recommended that research several recommendations, as follows:

1) To develop new types of high temperature, salinity and drought conditions that will prevail under conditions of climate change, and to develop new types of short growth season to reduce water needs, as well as to change the dates for agriculture, including appropriate to weather conditions, as well as cultivation of new items in appropriate The appropriate climate to increase crop yield of water unit for each crop, such as cultivation of wheat bear the high temperatures, drought-resistant and agriculture in time with good distribution of items on geographical areas, and the expansion of winter crops such as lentils, beans, and other municipal, it is likely that these measures to prevent expected negative effects, or, at least, alleviate the negative effects.

2) Reduce crop area of wasteful water consumption, or at least not to increase the size of such as rice, sugar cane, alternative crops and give the same purpose and water consumption and lower growth such as the cultivation of sugar beet instead of sugar cane.

3) The application of the methods of the best in land management such as improving fork soil water management and erosion control, plow soil for maintenance, and other farming can have a major role in carbon sink compensatory mechanism on the contribution of agriculture to greenhouse gasses.

4) The use of irrigation systems more effectively and provide better protection of coastal areas and farms, in order to mitigate the effects of climate change.

5) The completion of the severe shortage of available data and information on the negative effects of climate change on different sectors of development in Egypt, in particular the issue of the internal and external migration, and the establishment of a full database continuing to occur, in advance of the study, to encourage scientific research and technology in all issues related to climate change and develop specific plans and financing is clear.

6) Attention regionalization studies where can know the ways in which to overcome, or, at least, alleviate the shortage in crop productivity adversely affected by this phenomenon.

\section{References}

[1] Fawaz, M.M. and Soliman, S.A. (2015) Economic Study of Climate Changes and Its Effects on Sustainable Agricultural Development in Egypt. Egyptian Journal of Agricultural Economics, 25, 1177-1196.

[2] Intergovernmental Panel on Climate Change (IPCC) (2007) New Assessment Methods and the Characterization of Future Conditions. Fourth Assessment Report, Chapter Draft IPCC.

[3] El-Raey, M. (2000) Coastal Zone Development and Climate Change Drill Down of Climate Change on Egypt. ECRP.

[4] www.fao.org/climatechange/unfccc-bonn-2015

[5] Intergovernmental Panel on Climate Change (IPCC) (1991) The Seven Steps of the Assessment of the Vulnerability of Coastal Areas to Sea Level Rise-A Common Methodology “Intergovernmental Panel on Climate Change”. Response Strategies Working Group, Advisory Group on Assessing Vulnerability to Sea Level Rise and Coastal Zone Management, Revision No. 1.

[6] www.worldwatch.org/node/4839

[7] Fayyad, S. (2009) Drill Down of Coupled with and Climate Changes on Food Gave in “Afro-Asian”. Journal of Rural Development, xxxxii, 86.

[8] The Ministry of Agriculture and Land Reclamation (2009) Sustainable Agricultural Development Strategy until 2030. The Ministry of Agriculture and Land Reclamation, Cairo. 
[9] W.C.E.D. (World Commission on Environment and Development) (1987) Our Common Future. Brundtland, G.H., Ed., Oxford University Press, Oxford, 400 p.

[10] Parliamentary Commissioner for the Environment (2004) See Change: Learning and Education for Sustainability. New Zealand Government, Wellington, 14.

[11] The Egyptian Central Agency for Mobilization and Statistics (2014) The Report Issue.

[12] UNEP/WHO (1999) Identification of Priority Pollution Hot Spots and Sensitive Areas in the Mediterranean. UNEP Regional Seas Reports, Map Tech, Series No. 124, 86 p.

[13] Sentini, G. (1991) Implication of Climatic Changes for the Nile Delta in Environmental and Societal Printing Is of Climate Changes and Sea-Level Rise in the Mediterranean Sea Region. Jefic, L., Milliman, J.D. and Sestini, G., Eds., E. Arnold, London.

[14] Strzepek, K.M., Yates, D.N. and El Quosy, D.E. (1996) Vulnerability Assessment of Water Resources in to Climate Change in the Nile Basin. Climate Research, 6, 89-95. http://dx.doi.org/10.3354/cr006089

[15] Tasaadyet, B. (2013) The Impact of Climate Change on the Economy and Sustainable Development with Reference to the Case of Algeria. First National Forum on Environment and Sustainable Development-Climate Change, Pollution, University of Bouira, Algeria.

[16] http://www.eeaa.gov.eg/arabic/main/env_ozone_ecc_neg.asp 